\title{
ISLAMIC EDUCATION IN MULNITHI AZIZSTAN MADRASA PATTANI SOUTH THAILAND
}

\author{
Hussam Dueramae, Azhar Arsyad, Sitti Syamsudduha, \\ Muljono Damopolii \\ Islamic Council of Pattani, Thailand \\ 63 M1 Bang Tung Naren, Bothong Nongchik Pattani, \\ Thailand 94170 \\ Email : hsaziz8506@gmail.com; azhararsyd@gmail.com; \\ st.syamsudduha@uin-alauddin.ac.id; \\ muljono.damopolii@uin-alauddin.ac.id
}

\begin{abstract}
The main issue of this research is how the historical review of Islamic education in Mulnithi Azizstan Madrasa in Pattani-Southern Thailand. This type of research is a descriptive qualitative research that uses phenomenological, pedagogical, and psychological approaches. The researcher took the location in Mulnithi Azizstan Madrasa Pattani South Thailand. The findings showed that the early history of Islamic education in Pattani Thailand began in 1961 in the government of Sarit Tanarat by proposing a modernization program for Islamic boarding schools which was transformed into a private Islamic education school. After that policy, the growth of Islamic boarding schools is increasing rapidly. One of them is the Mulnithi Azizstan Madrasa. The concept of Islamic education institution in Mulnithi Azizstan Madrasa initially used the concept of Suffah in the time of its establishment. At present, the madrasa uses the concept of Halaqah and Majelis as the ways for students to learn. Finally, Mulnithi Azizstan Madrasa changed the learning system into each class.
\end{abstract}

Keywords: Islamic Education Institution, Muslim Minority Countries, and Islamic Education. 


\section{Introduction}

Islam has a tradition of dichotomy more than a thousand years ago. But the dichotomy about education is often felt in Western modern science which underestimates the scientific status of the religious sciences. ${ }^{1}$ According to Tuan Ilham Nuereng, Islamic education is under the influence of Western modernism, which raises various kinds of problems that require effective and efficient strategies in solving those problems caused such as human moral decadence, and also when faced with the issue of sunnatullah, namely pluralism, whether cultural pluralism, politics, religion, thought and so on, or even the development of value-free science and technology. ${ }^{2}$ The opinion of Tuan Ilham Nuereng occurred in Southern Thailand, especially in Pattani. The Islamic boarding institution in Pattani is so important but the authenticity of the Islamic boarding has now undergone many changes to fulfill the will and fundamentals of national lessons determined by the central government. ${ }^{3}$ In that way, there are currently Islamic boarding institutions that teach yellow books and there are also Islamic boarding institutions that turn into madrasa schools.

1 Mualimin, "Lembaga Pendidikan Islam Terpadu" AlTadrkiyyah: Jurnal Pendidikan Islam, Volume 8, $1^{\text {st }}$ Edition (2017), p. 102.

2 Zamrony, "Arah Baru Pendidikan Islam: Membangun Epistemologi Pendidikan Islam Monokhotomik" Dinamika Ilmu Journal of Education, Vol 10 no. 2. (2010), p. 2.

3 M. Zamberi A. Malik, Pattani dalam Tamdun Melayu (Kuala Lumpur: Dewan Bahasa dan Pustaka, 1994), p. 98. 
The spread of traditional Islamic education in Southeast Asia cannot be known as certainty. It is similar to Southern Thailand. But according to Ahmad Umar, "Traditional Islamic boarding education began to exist in Pattani or Southern Thailand since the arrival of Islam in Pattani then later developed by the people of Pattani (Southern Thailand) for 300 years before the King of Pattani, Sultan Ismail Syah, embrace to Islam (1488-1511)". ${ }^{4}$

The process of Islamic education has been going on throughout the history of Islam in Thailand and developed in line with the development of Islam and culture on the surface of the earth. Furthermore, the process of Islamic education in Thailand is carried out by Muslims for only around 15 percent compared to Buddhists with around 80 percent. ${ }^{5}$ That is why the development of Islamic education in Thailand always experiences obstacles even though Islamic education is one that is considered important for the minority of the Muslim population. Therefore, it is necessary to carefully review the history of the development of Islamic education in Southern Thailand. The Malay Traditional Education System is a system that appears in Pattani. Pattani is a Malay kingdom that was once sovereign in the past and has an area consisting of the provinces of Narathiwat, Yala, Pattani, Satun, and some parts

${ }^{4}$ Ahmad Umar Chapakia, Politik dan Perjuangan Masyarakat Islam di Selatan Thailand 1902-2002, p. 25.

${ }^{5}$ Helmiati, Sejarah Islam Asia Tenggara (Bandung: Nusa Media, 2011), p. 231. 
of Songkhla province, namely Chana, Tepa, Natavee, and Sabayoy districts.

The Minister of Education formed a constitution about the core curriculum for Basic Education in 2008, and then the Education Zone of the local authority and all schools must be affiliated with basic education where the direction and framework of curriculum development are to develop students and adolescents in Thailand. Improving the quality of knowledge and skills is very necessary to support the means of livelihood to be able to live with the community and fulfill their needs while allowing students to learn religious sciences based on their beliefs. For schools with students who are predominantly Muslim, Islamic Education needs to be taught. Islamic studies with special material learning aim to provide students with knowledge and understanding based on the principles in Islamic teachings.

If the study of Islamic Education Institution has only been focused on the majority Muslim region with all its advantages, then special attention is needed to form appropriate policies in overcoming the education gap for Muslim minority countries. Therefore, extracting information, especially historical research, is needed to further examine the concept of what Islamic education in Southern Thailand has applied for decades. 


\section{THEORETICAL BASIS}

\section{The Concept of Islamic Education}

The word education in Greek is known as pedagogues which means a guide for children. Paedagogos comes from the words paedos (son) and agoge (I guide). ${ }^{6}$ In the study of the treasures of educational thought, it is necessary to know in advance about two important terms that are almost the same form and are often used changibly in the world of education. The two important terms are "pedagogy" and "pedagogic." Pedagogy means education, while pedagogic means the science of education. ${ }^{7}$

Education in essence contains three elements, namely educating, teaching, and training. ${ }^{8}$ M. Arifin in Syahruddin Usman said that education is an effort of conscious adults to guide and develop the personality and basic abilities of students, both in formal and informal education. ${ }^{9}$ According to Hampherey Edwad in the International Encyclopedia, "Education means crease of skills development of knowledge and understanding as a result of training or experience training". ${ }^{10}$

6 Djumransjah, Filsafat Pendidikan (Malang: Bayumedia Publishing, 2004), p. 22.

7 Choirul Mahfud, Pendidikan Multikultural (VII Print; Yogyakarta: Pustaka Pelajar, 2014), p. 31.

8 Uyoh Sadullah, Pedagogik (Imu Mendidik) (I Print; Bandung: Alfabeta, 2010), p. 7.

9 Syahruddin Usman, Ilmu Pendidikan (Perspsktif Teoritis) (I Print; Makassar: Alauddin University Press, 2013), p. 2.

10 Hampherey Edward, Encyclopedia Internasional (New York: Glorier Incorporated, 1975), p. 247. 
The more specific formulation of Islamic education is carried out by Islamic education leaders by contributing their thoughts. One of them is Zakiah Daradjat that defines Islamic education as a business and activity carried out to convey religious appeals by preaching, delivering teachings, giving examples, practicing the skills by doing, motivating, and creating a social environment that supports the implementation of Muslim personal ideas. ${ }^{11}$ Omar Muhammad al-Toumy as-Syaibany defines Islamic education as a process of changing behavior that occurs in individuals and society. ${ }^{12}$ From the above understanding, it can be concluded that Islamic Education is all activities carried out by someone to help a person or group of students in instilling and developing Islamic teachings and values to be used as a view of life that is applied in their daily lives.

\section{Basic Islamic Education}

Hasan Langgulung in Azyumardi Azra said that the Qur'an as the basis of Islamic education contains several positive things for the development of education. They are respect for human reason, scientific guidance, not against human nature, and maintaining social needs. ${ }^{13}$ According to Islamic teachings, Islamic education is God's command and

11 Zakiah Daradjat, Ilmu Pendidikan Islam (Jakarta: Bumi Aksara, 1991), p. 27.

12 Omar Muhammad al-Toumy as-Syaibany, Falsafah Pendidikan Islam, Terj. Hasan Langgugulung (Jakarta: Bulan Bintang, 1979), p. 134.

13 Azyumardi Azra, Pendidikan Islam: Tradisi dan Modernisasi di Tengah Tantangan Millennium III (I Print; Jakarta: Kencana, 2012), p. 9. 
is a manifestation of worship to Him. The Word of God in the Qur'an, that is:

Quran Surah al-Nahl 16: 125.

Invite to the way of your Lord with wisdom and good instruction, and argue with them in the best way. Indeed, your Lord is most knowing of who has strayed from His way, and He is most knowing of who is [rightly] guided. ${ }^{14}$

The verse understood by some cleric explains three types of da'wah methods that must be adapted to the objectives of da'wah. Scholars who have high knowledge are instructed to deliver da'wah with wisdom, namely dialogue with wise words according to their level of intelligence. Lay people are instructed to apply mau'is ah, which is to give advice and parables that touch the soul according to their simple level of knowledge. While the command for abl al-Kitab and adherents of other religions is jihal debate in the best way, namely with logic and subtle rhetoric and free from violence and swear. ${ }^{15}$

The Prophet's Hadith is:

(From Abdullah bin Umar The Prophet said, "Convey (my teachings) to the people even if it were a single Aayah (Verse, sentence)"

${ }^{14}$ Departemen Agama RI, al-Qur'anul Karim Terjemah dan Tajwid Berwarna disertai Tafsir Ringkas Ibnu Katsir, p. 87.

15 M. Quraish Shihab, Tafsir al-Mishbah, Vol. 7 (II Print; Jakarta: Lentera Hati, 2004), p. 386.

${ }^{16}$ Imam Bukhari, Shahih Bukhari, Juz III (Beirut-Libanon: Darul Kutub al-Ilmiyah, 1992), p. 500. 
The second basis of Islamic education is Hadith or the Sunnah of the Prophet. Zakiah Daradjat said that like the Qur'an, hadith also contains aqidah and syari'ah. Hadith contains instructions (guidelines) for the benefit of human life in all aspects to foster the people to become whole human beings or Muslims who fear. For this reason, the Prophet became the main teacher and educator. He educated: first by using the house of al-Arqam ibn abi al-Arqam, second by utilizing prisoners of war to teach reading and writing, third by sending friends to the areas that had just converted to Islam. All of that is an education in the framework of the formation of Muslim human and Islamic society. ${ }^{17}$ So hadith is the basis of Islamic education.

To strengthen the position of hadith as a source or basis for educational inspiration and knowledge, it can be seen from the word of Allah QS al-Nisa 4: 80:

He who obeys the Messenger has obeyed God; but those who turn away - We have not sent you over them as a guardian. ${ }^{18}$

And Surat al-Hashr 59: 7.

... And whatever the Messenger has given you - take; and what he has forbidden you - refrain from.... ${ }^{19}$

17 Zakiah Daradjat, et.al., Ilmu Pendidikan Islam (X Print; Jakarta: Bumi Aksara, 2012), p. 21.

18 Departemen Agama RI, al-Qur'anul Karim Terjemah dan Tajwid Berwarna disertai Tafsir Ringkas Ibnu Katsir, p. 91.

${ }^{19}$ Departemen Agama RI, al-Qur'anul Karim Terjemah dan Tajwid Berwarna disertai Tafsir Ringkas Ibnu Katsir, p. 546. 
The verse above can be clearly understood that the position of the Prophet's hadith is the main basis used as a reference for the implementation of Islamic education. Hadith has two main benefits in the world of education. The first benefit is that the hadith can explain the concept and perfection of Islamic education following the Qur'an. Second, hadith can be a good example in determining the method of education, for instance making the life of the Messenger of Allah with his companions or children as a means of planting faith.

\section{RESEARCH METHOD}

This research is a historically based qualitative study. The methodological approach taken in this research is the phenomenology approach and the scientific approach. The scientific approach uses a pedagogical approach and a sociological approach.

The primary data source of this research is the leader and all staff under the auspices of the Islamic education institution of Mulnithi Azizstan Madrasa in Pattani, Southern Thailand. The types of instruments ${ }^{20}$ used in this research include interview guidelines, observation guidelines, and checklists. This research uses several data collection methods; observation of Islamic education institutions in Pattani Southern Thailand, interviews, and documentation.

${ }^{20}$ Instrument is a research tool in the form of a set of tests and so on to collect data as processing material. Ministry of Education and Culture of the Republic of Indonesia. 
The data analysis technique used in this research is an interactive model developed by Miles and Huberman which began with data collection, data presentation, and conclusion or verification. To analyze qualitative data in the form of interviews, documents, and observations, the researcher made field notes by sorting, classifying, making summaries, and ending by giving meaning to the data. ${ }^{21}$

Qualitative methods are used because the data were collected in the form of words and images so that it is possible to carry out analysis by considering various information. Data analysis is carried out continuously both in the field and after in the field. The analysis was carried out through data screening, classification, and retesting. The collected data were filtered and organized into categories and interconnected.

Drawing conclusions or verifying data is an attempt to obtain the truth and authenticity of data from the informant. In verification of data, the validity of data sources or the level of objectivity of the data will be prioritized as well as the linkages between the data sources with one another and then concluded. At this conclusion, the researcher draws conclusions and targets as the final part of the research.

${ }^{21}$ Sugiyono, Metode Penelitian Pendidikan: Pendekatan Kuantitatif, Kualitatif dan ReD, p. 248. 


\section{RESULTS AND DISCUSSION}

Mulnithi Azizstan Madrasa is located in a rural area, precisely at Azizstan Islamic boarding, placed at Jalan Phetkaseam No. 119 M. 7 T. Napradu A. Khokpho C. Pattani 94180, Southern Thailand. In terms of location, the madrasa is quite strategic. Even though the madrasa is in a rural area, it is on the edge of the highway so it is supported by easy access to the madrasa. To reach this madrasa is very easy because this madrasa is only about 10 meters from the highway, namely Jalan Phetkaseam. Besides, the location is easily accessible by both private and public vehicles. In this area, there are quite several public modes of transport operating so it is not difficult to reach this madrasa. The boundaries of Mulnithi Azizstan Madrasa in Pattani are as follows:
a. North Side: Bordering the highway
b. West Side: Bordering Thungna village
c. South Side: Bordering Beiuka village
d. East Side: Bordering Saiak village ${ }^{22}$

Mulnithi Azizstan Madrasa stands as an educational institution modeled on Islamic boarding schools. Its name is Azizstan Islamic boarding which was founded by Tuan Guru H. Abdulaziz bin Sinik Abdulwahab in 2469 B/1953 M. Tuan Guru H. Abdulaziz bin Sinik Abdulwahab was born in 2440 $\mathrm{B}$ and died in $2517 \mathrm{~B}$ which coincided with 1897-1974 M.

22 Observation, November 10, 2017. 
Born in the village of Khadok Ampe Nongci Changwat Pattani and had two wives.

The first wife was named Khodijah and had five children. The first child named Husein bin Abdulaziz. He died in Mecca while studying there. The second child was named Maryam bintii Abdulaziz and died in 2012. The third child named Romlah binti Abdulaziz, the fourth child named Aisyah binti Abdulaziz who died in 2008. The last child named Abdulwahab Abdulwahab bin Abdulaziz who is now in charge of taking care of Mulnithi Azizstan Madrasah administrators.

Second wife named Rokiah. They had six children. The first child named Gosali, died in 2008. He was a former head of Mulnithi Azizstan Madrasa. The second child was named Fauzia bintii Abdulaziz, the third named Jamaluddin Abdulwahab bin Abdulaziz, the fourth was Buraheng Abdulwahab bin Abdulaziz, the fifth was Faizah duramae bintii Abdulaziz, and the last was named Zulkifli Abdulwahab bin Abdulaziz.

Tuan Guru H. Abdulaziz bin Sinik Abdulwahab fostered Azizstan Munithi Madrasa during the second world war which was $1 \mathrm{~km}$ from Napradu train station. At that time in the Napradu area, none of them were Muslim and there were no Islamic schools. He filled the yellow book recitation in the prayer room he made himself after five prayers. Students whom Master got were students from Bangkok, Negeri Sembilan Malaysia. 
Tuan Guru H. Abdulaziz bin Sinik Abdulwahab built two more Islamic boarding schools in the village of Lubuk Panjang Chakwat Yala. The village is a village that is predominantly Muslim but there is no Islamic school. The second Islamic boarding school is Phatanakasiksa Ampe Hadyai Chakwat Sokhala Madrasa which was fostered by his daughter-in-law Yusuf Hj. Ibrahim, husband of Aisyah binti Abdulaziz.

Tuan Guru H. Abdulaziz bin Sinik Abdulwahab made a masterpiece of a book entitled the understanding of children or with the holy book of the nature of 20 to be an original book of Aqeedah and Fiqh which are used as guidelines in Islamic boarding schools in Pattani. The book is still taught in Azizstan Munithi Madrasa by Abdulwahab bin Abdulaziz once a week on Wednesday after sunset. Tuan Guru H. Abdulaziz bin Sinik Abdulwahab was the head of Islamic Majelis in Pattani Southern Thai. Now, Munithi Azizstan Madrasa has a land area of 40 hectares and is divided into two parts, to build a madrasa of 19,5 hectares, and a community residence of 20,5 hectares with a total of around 150 families. $^{23}$

\section{The History of Establishment and Development Process}

Mulnithi Azizstan Madrasa started to become an educational institution modeled on an Islamic boarding

23 Interview with Tuan guru H. Abdulwahab Abdulwahab, Owner of Mulnithi Azizsthan Madrasah. Pattani on November 10, 2017. 
school. The name is Azizstan Islamic Boarding School which was founded by Tuan Guru H. Adulaziz Abdulwahab in 2496 B/1953 M and located at No. 119 M.7 T. Napradu A. Khokpho C. Pattani Southern Thailand. The leadership of the madrasa is divided into 2 , namely the leadership of Tuan $\mathrm{H}$. Abdulaziz and Tuan H. Abdulwahab Abdulwahab. The detailed explanation is as follows:

\section{a. Tuan H. Abdulaziz bin Abdulwahab (2496-2513 B/53- 1970M)}

Mulnithi Azizstan Madrasa is one of the Islamic education institutions located in Thailand which aims to develop Islamic teachings and Islamic noble values so that the students of Mulnithi Azizstan Madrasa can be happier in the world and the hereafter. Mulnithi Azizstan Madrasa was established at the end of the period after Islam in Pattani entered and developed at that time.

In $1953 \mathrm{M}$, he felt responsible for developing Islamic teachings in the region. In the same year, a religious school was established under the name of Azizstan Madrasa. The name of the school has the meaning of giving to the owner of the madrasa because, at that time, the madrasa was led by Tuan Guru H. Abdulaziz Abdulwahab. Then the population grew so a Balashah (Musholla) was standing. The mosque became a place of worship and as a place of recitation of the Quran as well as a place to study the teachings of Islam, namely as a place of education.

In its development, students were increasing, both from Pattani province and the surrounding provinces such as 
Yala province, Narathiwat Province, and Songkhla Province. There are even those from abroad such as Malaysia and Indonesia. After getting more supporters, the madrasa can build a place of education. The assistance of teaching staff also increased to be able to balance with the students' number. Azizstan Islamic Boarding School is increasingly growing.

The madrasa received much support from abroad so they could build educational facilities. Besides, there was also additional assistance to teach to fit the number of students. Likewise, with Mulnhhi Azizstan Madrasa, which was increasingly developing both from the curriculum and physical buildings, the Azizstan Islamic boarding has turned into a Private Religious School or Madrasa.

In 1956, M. Tuan H. Abdulaziz Abdulwahab gave a mandate to Tuan H. Wea Uma H. Awea to arrange permission from the government. With the hard work and effort of Tuan H. Wea Uma, he obtained official permission from the government. That was from the Ministry of Education (Kraksuang seksatikan) and immediately received assistance from the Department of Education Level II Yala for repairs. Azizstan Madrasa was also permitted to become private madrasa, and as the first madrasa in Pattani province to teach Islam in a madrasa.

This private madrasa is recognized by residents of Pattani province and the surrounding provinces. Every year, this madrasa has to make new buildings because of the increasing number of students and the Islamic teaching and learning activities according to curricula such as madrasas that 
have been determined by the Ministry of Education. General knowledge in the early stages still used the curriculum to educate parents at the elementary level, then it got the help of teaching staff from the Department of Education, specifically for general science and special sciences such as medical and design sciences like modeling (chairs, tables, etc.), and cooking science that is taught to the students so students can make a living to practice so that they can live upright. ${ }^{24}$

\section{b. Tuan H. Abdulwahab Abdulwahab (2513/1970- present)}

In 1970, Tuan H. Abdulaziz Abdulwahab gave his full authority to his son Tuan H. Abdulwahab Abdulwahab and also as the owner and leader of the madrasa. After Tuan $\mathrm{H}$. Abdulwahab Abdulwahab accepted a position as a leader, he immediately accepted the Religious and general science education curriculum. In 1973, Tuan H. Abdulwahab Abdulwahab could open general science to the first middle class with a curriculum equated by the Ministry of Education.

In 1984, there was an agreement between the Mulnithi council and the madrasa leader to change the original name of Azizstan Islamic Boarding to Mulnithi Azizstan Madrasa. Then in 1986, the Mulnithi Azizstan Council (Management Staff) strongly agreed on the implementation of school management. With the contribution of the Ministry of Education, the religious science curriculum from the general science curriculum is carried out by the school. The

24 Documentation of Prawat Kung Rong Rian coming from Thai which has the meaning of Madrasah History, on November 10, 2017. 
curriculum run by Mulnithi Azizstan Madrasa is the Buranakan curriculum, namely:

1) Islamic education curriculum at Mattyom Thon Thun level, ${ }^{25}$ the year $2535 \mathrm{~B} / 1986 \mathrm{M}$

2) Islamic education curriculum at Mattyom Than Pelai level, ${ }^{26} 2535$ B/1986 M. Until now, Mulnithi Azizstan Madrasa is still running with the Buranakan curriculum.

Therefore, in the leadership of Tuan H. Abdulwahab Abdulwahab, there have been many evolving changes with the increasing religious education and general education. The system led holds the role of regulator or headmaster who only serves as the person in charge of the principal. While other fields are given the responsibility to certain people who have sufficiently good abilities such as finance, education, school development, and student affairs. ${ }^{27}$

Azizstan Mulnithi Madrasa still stands firm in Pattani and now, the madrasa is 65 years old. Many developments occur in this madrasa. In the past, this madrasa was an

${ }^{25}$ Mattyom Thon Thun, coming from Thai, which is a level of general learning. This level of education has 3 years, namely M.1, M.2, and M.3. This level has similarities with education in Indonesia, namely education at the junior high school level.

${ }^{26}$ Mattyom Thon Pelai coming from Thai, which is a level of general learning. This level is an advanced level from Mattyom Thon Thun (Middle School). This stage of education has 3 years, namely M.4, M.5, and M.6. This level has similarities with education in Indonesia, namely education at the high school level.

27 Documentation of Prawat Khong Rong Rian coming from Thai which has the meaning of Madrasah History, On November 10, 2017. 
ordinary boarding school that had only a few students. But now, the Islamic boarding school is developing and turns into a fairly large and important madrasa in the spread of Islamic teachings in Pattani. Until now, the madrasa has thousands of students.

Since Mulnithi Azizstan Madrasa stood around 65 years ago, there have been thousands of alumni who graduated in this madrasa. Many alumni from this madrasa continued their education in several government colleges both domestic and abroad. Some became community leaders with various positions such as lecturers, teachers, school leaders, civil servants, preacher priests, bilal, kindergarten teachers, and others. ${ }^{28}$

The reality of the management of Islamic educational institutions in Pattani, Southern Thailand, shows the development from year to year. After the policy of modernizing Islamic boarding schools to modern Islamic educational institutions, the institutional management model, curriculum and subject matter are monitored directly by the government. Direct monitoring from the government is in the form of direct education workers from the government in every Islamic education or madrasa. Many lessons such as Fiqh about the chapter of jihad must be abolished in the curriculum considering that this is a lesson that can be used

28 Tuan guru H. Abdulwahab Abdulwahab, Owner of Mulnithi Azizsthan Madrasah. Interview, Pattani on November 10, 2017. 
to mobilize the masses to carry out rebellions against the Thai government.

In general, the result of the modernization of the government towards Islamic boarding schools in Pattani or Islamic schools has the same management model of the institution and is centered on the government curriculum. This situation is different from the situation in Indonesian boarding schools that have an independent curriculum. More specific things in the management of Islamic education institutions in Southern Thailand Pattani can be seen from the basis and objectives of education management, organizational structure, curriculum, teachers, and facilities in Mulnithi Azizstan Madrasa, which is the oldest madrasa school in the Napradu area. The above findings can be synchronized with the full pantron theory which has bureaucratic management theory.

2. The Concept of Suffah, Kuttab, Halaqah, and Majelis in Islamic Education Institute in Pattani, Southern Thailand

\section{a. Suffah}

Suffah is a place that has been used for educational activities. Usually, this place provides accommodation for newcomers and those who are classified as poor. Here, students are taught to read and memorize the Qur'an correctly and also be made Islam under the direct guidance of the Prophet. ${ }^{29}$ Today, Islamic education in the Suffah concept is the same as education in Islamic boarding schools. This is not

\footnotetext{
${ }^{29}$ Ramayulis, Sejarah Pendidikan Islam, p. 45.
} 
much different from the conditions in Mulnithi Azizstan Madrasa as Tuan Guru Abdulwahab Abdulwahab explained that:

"Suffah is the same as an Islamic boarding school in the present. In the past, this madrasa used Suffah to build an Islamic school. The madrasa originated from 20 students from various places of Pattani who came to study Religion. Then the teacher in Islamic boarding school teaches yellow books like the antidote book for the heart, the nature of twenty, matan ajrumuiyah, and musholli in the Tuan Guru mosque. The students did not only come from Pattani. There were also from Northern Thailand, Thailand, the capital city of Bangkok, and people from other countries like Cambodia, Myanmar, and Malaysia." ${ }^{30}$

The results of the interview above describe an educational institution as a boarding school in which there are at least 5 elements, namely: Tuan Guru/Kyai/teacher, santri/students, pengajian/ recitation, dormitory, and mosque with all the activities of religious and social education. Mulnithi Azizstan Madrasa was originally a salafiyah/ traditional boarding school or used the Suffah concept. Learning Islamic sciences is done individually or in groups by concentrating on classical Arabic books. The gap is not based on a unit of time but based on the end of the book being studied. In this way, students can more intensively study a branch of science.

${ }^{30}$ Tuan guru H. Abdulwahab Abdulwahab, Owner of Mulnithi Azizsthan Madrasah. Interview, Pattani on November 12, 2017. 
However, even though Mulnithi Azizstan Madrasa has changed from Islamic boarding school to madrasa, the political system in Thai region still uses the Suffah concept, likewise this school. With the santri who want to learn religion, Tuan Guru creates and develops Muslim personalities, namely the personality of the faithful and fearful of Allah SWT, noble character, beneficial to the society, as a servant of society, independent, free and firm in personality, spreading religion, or uphold the religion of Islam and the glory of Muslims amid society ('izzul Islam walin Muslim), and love science to develop personality. This is made clear by what Tuan Guru H. Abdulwahab Abdulwahab said that:

"This madarasa initially had nothing to do with the government and was called an Islamic boarding. At first, Tuan Guru only wanted to share knowledge in the community and bought a place with Tuan Guru's funds to build a musholla as a place to study and make a dormitory for students who live in the Islamic boarding. Then the santri look for foods by themselves by maintaining plants, chickens, and catfish for lunch and dinner. Now, Suffah continues to be used by assimilating poor students by freeing dormitory payments, clothing, and books". ${ }^{31}$

\section{b. Kuttab}

Kuttab education is a place to learn to write or also called low school level, as a place of learning for children. The material taught is literacy which is generally taken from Arabic

31 Tuan guru H. Abdulwahab Abdulwahab, Owner of Mulnithi Azizsthan Madrasah. Interview, Pattani on November 12, 2017. 
poetry and proverbs. The Kuttab is a place that focuses on literary reading material, Arabic poetry, and numeracy learning. But after Islam came, the material was added to the Qur'anic literacy material and understood Islamic laws. The condition of the Kuttab was very simple at first, namely: (a) Learning to read and write, (b) Reading the Qur'an and memorizing it, and (c) Learning the main points of Islam, such as ways of ablution, prayer, fasting, and so on. The sciences taught at the middle and high levels consist of: (a) the Qur'an and its interpretations, (b) Hadith, and (c) Fiqh (tasri').

The implementation of the Kuttab concept at Mulnithi Azizstan Madrasa has different stages of the process when the construction period from Islamic boarding to madrasa. During the development period, Tuan Guru Abdulwahab Abdulwahab explained that:

"In madrasa, there were no classes, there were no buildings so that all the level of learning was in one place, namely the mosque or prayer room. The person who teaches is Pak Kyai, Tuan Guru Abdulaziz Abdulwahab himself. He taught how to read the Qur'an, Fiqh, the good things of the books he wrote, and other yellow books. And after learning from Tuan Guru Abdulaziz Abdulwahab, senior santri taught junior santri to add an explanation at the mosque. After the cleric children returned from abroad, finally the level teaching method changed to classes. Initially, it started from Ibtidaiyah and Mutawassith only by using just one building. At that time, Azizstan Islamic 
boarding was registered as an official school in Thailand". ${ }^{32}$

The Kuttab concept is used by using 3 methods of education/teaching, including; oral, memorizing, and writing. Oral method is in the form of imla' dictation; al-sama' lecture method; and qiro'ah method that is usually used to learn to read. Memorizing methods are a common feature of every religious lesson, where students repeatedly read so that they can express it again and contextualize it in daily life, and in discussions, they can respond, break opponents, or argue with their new opinions.

The writing method is considered the most important method. This is useful for the process of mastering science, as well as for doubling the number of textbooks and helping to memorize religious lessons, especially the Quran and Hadith. The Kuttab concept itself represents the Azizstan Islamic boarding curriculum were to achieve the highest level in mastering the science of religion, a good religious basis is needed.

\section{c. Halaqah}

Halaqah means a circle. Halaqah is an Islamic educational institution on a level with advanced education or college. This system is a typical description of students who gathered to study at that time. The teacher usually sits on the floor while explaining, reading his essays, or commenting on

32 Tuan guru H. Abdulwahab Abdulwahab, Owner of Mulnithi Azizsthan Madrasah. Interview, Pattani on November 12, 2017. 
others about a work of thought. Halaqah at Mulnithi Azizstan Madrasa is held every Friday night after sunset prayer, especially for students who live in the dormitory. This Halaqah consists of memorizing Al-Qur'an and Hadith that has been determined. Every Halaqab is filled by seniors with one topic of religion.

\section{d. Majelis}

Majelis is an association that is used for scientific transmission activities from various scientific disciplines so that Majelis has a wide variety. Majelis in Mulnithi Azizstan Madrasa consists of Dakwah Majelis or well-known in Indonesia with Jama'ah Tabligh. Every Friday, some santri come to the community to preach with Jama'ab Tabligh.

\section{CONCLUSION}

One of the oldest madrasa in the South Napradu Pattani area is Mulnithi Azizstan Madrasa which stands as an educational institution modeled on Islamic boarding schools. The name is Azizstan Islamic boarding which was founded by Tuan Guru H. Abdulaziz bin Sinik Abdulwahab in 2469 B/1953 M. Tuan Guru H. Abdulaziz bin Sinik Abdulwahab was born in $2440 \mathrm{~B}$ and died in $2517 \mathrm{~B}$. The reality of managing Islamic education institutions in Pattani, Southern Thailand, after the policy of modernizing Islamic boarding school to modern Islamic educational institution in 1961, was considered important so that the management model of the institution, curriculum, and subject matter is monitored directly by the government. The modernization of the 
government towards Islamic boarding schools in Pattani or Islamic schools has the same management model of the institution and is centered on the government curriculum. The process of implementing the concept of managing Islamic education institutions at Mulnithi Azizstan Madrasa initially used the concept of Suffah when it was established. Until now, this concept has been carried out by assimilating students outside the region. By using the concept of Halaqah and Majelis as the ways for students to study, finally, Mulnithi Azizstan Madrasa changed the learning system into each class. Kuttab itself is an Islamic basic education institution at Mulnithi Azizstan Madrasa because the material taught is the basics for writing Arabic, learning aqeedah, and fiqh.

\section{REFERENCES}

Afif, Ahmad. "Model Pengembangan Pendidikan Islam Berbasis Multikultural", Tadrîs, Volume 27 No. 1 June 2012.

Al-Bukhari, Abu. "Abdillah Muhammad bin Ismail bin Ibrahim", Sabih al-Bukhari, Juz I. Beirut: Dar al-Fikri, $1401 \mathrm{H}$.

Amornwiwat, Sumon. Sombat Kong Karn Sek-Sa Thai, Bangkok:

Chulalongkorn, 2533B.

Arikunto, Suharsimi. Manajemen Penelitian. VII Print; Rineka Cipta, 2005.

------. Prosedur Penelitian: Suatu Pendekatan Praktik. XIII Print; Jakarta: Rineka Cipta, 2006. 
Auliahadi, Arki. "Dinamika Perjuangan Muslim Patani (Tinjauan Historis)", Fuaduna: Jurnal Kajian Keagamaan dan Kemasyarakatan, Vol. 1, No. 1, January-June 2017.

Azra, Azyumardi. Pendidikan Islam: Tradisi dan Modernisasi di Tengah Tantangan Milenium III. I Print; Jakarta: Kencana, 2012.

------. Pendidikan Islam: Tradisi Modernisasi Menuju Melenium Baru. I Print; Jakarta: Logos Wacana Ilmu, 1999.

------. Ensiklopedia Tematis Dunia Islam Asia Tenggara. Jakarta: Ichtiar Baru Van Hoeve, 2002.

Berglund, Jenny. "Publicly Funded Islamic Education in Europe and the United States" The Brookings Project on U.S. Relations with the Islamic World, ANALYSIS PAPER, No. 21, April 2015.

Bukhari, Imam. Sabih Bukhari, Juz III. Beirut-Libanon, Darul Kutub al-Ilmiyah, 1992.

Degeng, I Nyoman S. Ilmu Pengajaran: Taksonomi Variable, Jakarta: depdikbut, DIKTI, Proyek LPTK, 1989.

Departemen Administrasi Provinsi, Demografi2558. I Print; Bangkok, Thailand.

Departemen Agama RI, Al-Qur'anul Karim Terjemah dan Tajwid Berwarna disertai Tafsir Ringkas Ibnu Katsir. Jakarta: Jabal Raudhotul Jannah, 2009.

Departemen Pendidikan, Lak Sut Islam Suksa tam Lak Sut kan klang kan suksa khan pern tan. B.E. 2551.

Djumransjah. Filsafat Pendidikan. Malang: Bayumedia Publishing, 2004. 
Helmiati. Sejarah Islam Asia Tenggara. Bandung: Nusa Media, 2011.

Mahfud, Choirul. Pendidikan Multikultural VII Print; Yogyakarta: Pustaka Pelajar, 2014.

Malik, M. Zamberi A. Pattani dalam Tamdun Melayu, Kuala Lumpur: Dewan Bahasa dan Pustaka, 1994.

Mualimin, "Lembaga Pendidikan Islam Terpadu" AlTadrkizyab: Jurnal Pendidikan Islam, Vol. 8, $1^{\text {st }}$ Edition, 2017.

Sadullah, Uyoh. Pedagogik (Imu Mendidik) I Print; Bandung: Alfabeta, 2010.

Usman, Syahruddin. Ilmu Pendidikan (Perspsktif Teoritis) Cet, I; Makassar: Alauddin University Press, 2013.

Wahid, Abdul. "Pergulatan Pendidikan Agama Islam Di Kawasan Minoritas Muslim" Jurnal Walisongo, Vol. 19, No. 2, November 2011.

Wekke, Ismail Suardi dan Ambo Tang, "Kultur Pendidikan Islam Di Minoritas Muslim Inggris". THAQAFIYYAT, Vol. 17, No.1, June 2016.

------. dkk., "Pesantren, Madrasah, Sekolah, Dan Panti Asuhan: Potret Lembaga Pendidikan Islam Minoritas Muslim" Jurnal Imu Tarbiyah "At-Tajdid", Vol. 6 No. 1, January 2017.

Zamrony, "Arah Baru Pendidikan Islam: Membangun Epistemologi Pendidikan Islam Monokhotomik" Dinamika Ilmu Journal of Education, vol 10 no. 2. 2010. 